\title{
None Identified
}

National Cancer Institute

\section{Source}

National Cancer Institute. None Identified. NCI Thesaurus. Code C157432.

Nothing was identified. 